\title{
A narrative investigation into the meaning and experience of career success: Perspectives from women participants
}

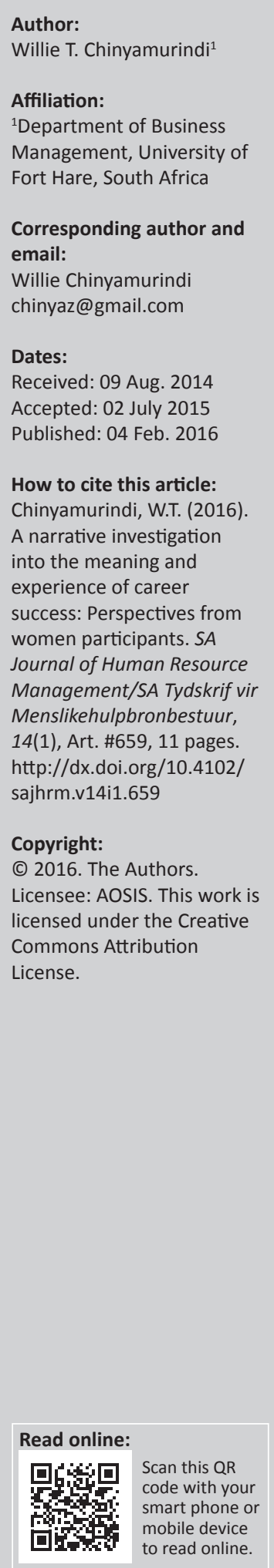

Orientation: In South Africa opportunities are being created that encourage more women to enter the workforce. Understanding how women conceptualise and experience career success affects not only their individual career development but also their general outlook in life.

Research purpose: To investigate how a sample of previously disadvantaged women distance learners conceptualise and experience the notion of career success.

Motivation for the study: Calls have been made for research incorporating a subjective understanding regarding career success, especially amongst minority groups.

Research approach, design and method: An interpretive approach was employed aimed at understanding individual experience and the interpretation of it. Unstructured interviews were conducted shaped by the objectives of the study amongst a sample of women $(n=25)$.

Main findings: Through narratives and stories, findings revealed career success to be conceptualised and experienced as (1) a means of professional attainment and recognition, (2) a contribution to society and (3) evident in material and non-material artefacts. Further, from the sample of women used in this research, the experience of career success considered not only socio-historical issues and community but also the cultural milieu. Education emerged as an enabler of individual pursuit and goals leading to career success.

Practical/managerial implications: An understanding of how career success is conceptualised and experienced by previously disadvantaged women can serve as a forerunner to individual specific career development interventions. The results of the study are therefore useful to both academics and practitioners in their formulation of interventions that enable individual career development.

Contribution: The experience of career success as found in this study through participant narratives and stories gave a picture of career development processes amongst previously disadvantaged groups in South Africa. These processes illustrate how individuals draw meaning and a sense of direction en route to career success, revealing aspirations affecting not only their career development but also their lived experience.

\section{Introduction}

Women in South Africa occupy a strategic position. Laws such as the Employment Act of 1998 have been credited with encouraging the involvement and increasing the number of women in key sectors of the South African economy (Mahlomaholo, 2011; Mkhize \& Msweli, 2011). Furthermore, initiatives such as Affirmative Action (AA) and Employment Equity (EE) have been introduced with the belief that they will achieve equality in a largely divided society (Czakan, 2006). The focus here is on giving organisations' AA and EE targets an opportunity to open a passage into their influence in the socio-economic cluster of the country (Booysen, 1999). This has been suggested to be a way to improve the lives individuals who are AA and EE targets (De Bruin, 2000).

Despite this progress through AA and EE initiaves, women remain under-represented in South African organisations (Booysen \& Nkomo, 2010; Moletsane \& Reddy, 2008). This underrepresentation has been attributed to the history of South Africa including the policy of apartheid (Sedibe, 2011). The ideological basis of apartheid was around 'separateness' by colour and this subsequently relegated women (Cottrell, 2005). In South Africa, the term 'previously disadvantaged' is used to describe those individuals or categories of persons who, prior to the new democratic South Africa, were unfairly discriminated on the basis of their race (Nefcorp, 2005). 
These individuals include mostly black African people, mixed race people, Indian people, women and people living with disabilities (Cottrell, 2005).

Traditional career development theories have been used to understand phenomena such as career success. However, such theories have been criticised for providing a static view of careers (Hirshi, 2011) and one that does not account for the possibility of complexity and the unpredictable nature of variables influencing career development (Patton \& McMahon, 2006). Others (e.g. Asuquo \& Inaja, 2013) highlight a shortcoming of traditional career theories in the omission of the needs of groups such as women, with a focus more of elite white men and matching them to jobs. Further, in understanding the career development processes of groups such as women, the empirical focus should move away from the matching of careers (as espoused in traditional career theories) to determining the factors that may retain and sustain individual career development in a demanding context (Watt, Richardson, \& Wilkins, 2014).

Traditional career theories have also been noted for their omission of environmental context in shaping careers. Ozbilgin (2011) advocates a more situated (geographical and cultural) perspective in understanding career development that is contextually relevant. This fits in with calls for studies to be less general and more specific in relation to contextual issues affecting people (Edwards, 2011; Khapova \& Arthur, 2011). This is an important focus, especially given the environmental changes that shape individual careers in contemporary society (Chudzikowski \& Mayrhofer, 2011). Such a research focus is believed to not only aid understanding of career development, but also challenge traditionally held views of a career being linear and following a developmental stage approach (Sullivan, 1999; Sullivan \& Baruch, 2009).

To aid the retention of women in organisations, researchers continually argue for an investigation into how women experience success (Maxwell \& Ogden, 2011; Pheko, 2014). This is important given that such groups of people have received little or no empirical focus (Themba, Oosthuizen \& Coetzee, 2012). Such inclusive approaches are helpful not only in modern career management practices, but also to keep up with changes (social, economic and political) that have happened in South Africa (Oosthuizen, Coetzee \& Mntonintshi, 2014). By applying this focus, it may be a useful launchpad to informing not just career development initiatives, but also the retention of women in organisations. Subsequently, this has an overall bearing on the lived experience of the individual (Price, 2009). However, little is still known in South Africa concerning individual career success as part of career development (Coetzee \& Gunz, 2012; Koekemoer, 2014).

There is also acknowledgement of the role distance learning can play on individual career development (Burgess \& Russell, 2003). Pityana (2009) notes distance education as addressing two key barriers faced by previously disadvantaged groups, namely location and lack of funds. Lemmer (2009) applauds distance education as popular for those individuals who require flexibility between work and study. In all this, distance education is the most popular mode of instruction especially amongst previously disadvantaged individuals (Department of Education, 2010; Department of Higher Education and Training, 2013). An understanding of the career development processes of previously disadvantaged individuals can be a starting point for career interventions specific to their situation.

Calls have been made for studies that focus on how distance learning can further develop human capital skill sets (Reimers-Hild, Fritz \& King, 2007) and individual career development (Burgess \& Russell, 2003; Chinyamurindi, 2012). Furthermore, qualitative methods are advocated as important in understanding the career development processes of previously disadvantaged individuals such as women (Maree, 2010, 2014, 2015) given that such individuals face complexity in their career development not often captured easily through the quantitative research paradigm. Such research approaches are applauded, especially in societies faced with a great deal of environmental complexity (Savickas, 2011).

Within this, Austin and Cilliers (2011) argue that given the macro environmental changes happening in South Africa, there is a need to investigate how such change impacts the individual and their career development using sample groups that have received scant empirical focus. One such sample group that remains 'understudied' in South African career research is previously disadvantaged individuals, which includes women (Schreuder \& Coetzee, 2012, p. 2), especially those individuals involved in lifelong learning (Braimoh, 2010) who are working and studying at the same time whilst subject to initiatives of economic redress.

\section{Research purpose and objectives}

Research into career success is growing in South Africa (e.g. Koekemoer, 2014; Pheko, 2014) and internationally (for an overview see $\mathrm{Ng}$, Eby, Sorensen \& Feldman, 2005). Nevertheless, there seems to be the need for further research on career success using different sample groups with their specific situations and experiences in mind. There is acknowledgement that the career development of women is theorised to be different from men $\left(\mathrm{O}^{\prime} \mathrm{Neil}\right.$ \& Bilimoria, 2005) and also that distance learning can aid individual career development (Braimoh, 2010; Burgess \& Russell, 2003; Chinyamurindi, 2012). The purpose of this study was to identify specific factors that influence the career success of women distance learners within the South African context, thereby helping to inform career interventions and improving the lived experience. The overall research question that guided this study was: What factors (given the South African context) influence the career success of women distance learners in South Africa? 


\section{Background of career success}

Career success is defined as the individual's accumulation of positive work-related and psychological outcomes from the work experience (Judge, Cable, Boudreau \& Bretz, 1995). By understanding the factors that influence individual framing of career success, this may impact career development in general (Gattiker \& Larwood, 1986).

Career success was once viewed as following an upward trajectory of lifetime employment in one organisation (Adamson, Doherty \& Viney, 1998). However, in view of the changing environmental context, this view may not be guaranteed (Maree, 2014; Savickas, 2011). Such a focus that pays attention to the complex and unpredictable nature of career development is receiving empirical focus and has been labelled as part of the 'new' agenda within career literature (Chudzikowski, 2012, p. 298).

The 'new' agenda in career literature is one that tries to identify the individual and organisational variables that influence individual framing of career success (Heslin, 2005). Given this, there is increasing empirical focus on understanding career development as part of this 'new' agenda (e.g. Joo \& Park, 2010; Ndzube, 2013; Price, 2009). Career success has been framed to be either objective or subjective (Baruch, 2006).

\section{Objective and subjective career success}

A distinction is offered between objective and subjective career success. The former is thought to strive for the observable, measurable and verifiable attainment (Dries, Pepermans, \& Rypens, 2009). An example of objective career success includes monthly salary and status (Abele \& Spurk, 2009). On the other hand, subjective career success is viewed as an individual's evaluation of the present achievements compared to their personal goals and expectations (Seibert \& Kraimer, 2001). Examples of subjective career success include career satisfaction (Greenhaus, Parasuraman \& Wormley, 1990) and job satisfaction (Ng et al., 2005). There appears to be an empirical slanting towards the use of quasiobjective measures of career success (Dries et al., 2009). The thinking here is the need to generate objective data that are observable and measurable based on scientifically tested instruments (Nicholson, 2000). Given the importance and popularity of career success in the academic press, there is continued focus on investigating those factors that influence or impede career success (Coetzee \& Schreuder, 2009; Koekemoer, 2014; Pheko, 2014).

\section{Predictors of career success for women}

A number of studies (mostly international) exist investigating the subjective evaluations of career success amongst women. Even with research using both male and female participants, there is limited focus on investigating career success (Koekemoer, 2014). A summary of international and national studies investigating the predictors of career success is shown in Table 1. Notably, based on Table 1, no study has investigated the factors that either contribute to or impede career success amongst women distance learners, despite a number of recommendations. For instance, Pheko (2014, p. 9) suggests the need for research around career success amongst 'women with similar profiles' like 'educational background'. The women to be used in this study are all from the previously disadvantaged cohort who are working and studying via distance learning. Others like Koekemoer (2014, p. 2) suggest that in South Africa research on career success is 'timeous' given the popularity of this research stream internationally. As its contribution, this study seeks to answers these calls.

\section{Research design}

\section{Research approach}

The study adopted a qualitative exploratory research approach. The rationale for this was that this approach was useful in understanding the factors influencing career success (Koekemoer, 2014). Such an approach allows for understanding of experience and the interpretation of it from the individual viewpoint (Hallebone \& Priest, 2009). The focus here is on understanding human experiences from a holistic and in-depth perspective (Vishnevsky \& Beanlands, 2004), rather than it being fragmented as often employed in survey-based techniques. This is done through collecting more situational information and extrapolating the meaning and purpose that individuals attach to their actions (Guba \& Lincoln, 1994).

\section{Research strategy}

Unstructured interviews were preferred over semi-structured interviews using a sample of career women who were working and studying at the same time. Stead and Watson (2006, p. 86) argue that semi-structured interviews tend to imply a 'search for specific course of events'. The focus of this research was not to impose any predetermined structure in understanding career success; semi-structured interviews would assume this predetermination. Unstructured interviews helped to allow participants to share freely their situation from their own points of view (Fraenkel \& Wallen, 2006). This allowed investigation into how individuals make meaning of their lived experiences (Walter, 2006). Participants could open up memories, reflect on experiences, elaborate on ideas and clarify responses during the course of the interview (Rubin \& Rubin, 2005).

\section{Research method}

\section{Research setting, sampling and participants}

The research project was part of a partnership between two institutions, one located in the United Kingdom (Open University Business School) and the other in South Africa (University of South Africa). The author of this article was pursuing his PhD studies with the United Kingdom institution and had also worked as a junior academic in South Africa. The South African institution had a regional 
TABLE 1: Summary of South African and international studies focusing on predictors of career success amongst women.

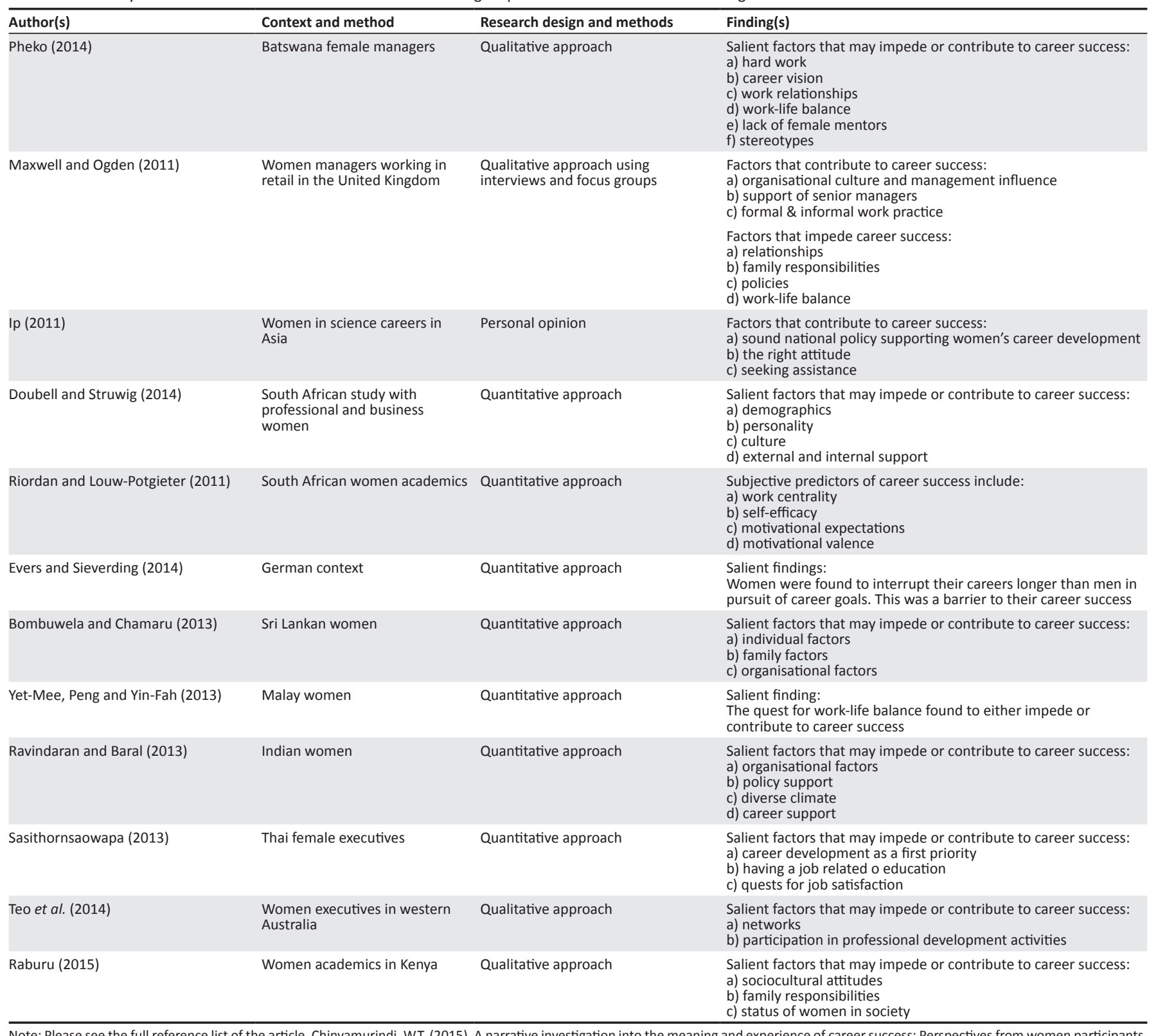

Note: Please see the full reference list of the article, Chinyamurindi, W.T. (2015). A narrative investigation into the meaning and experience of career success: Perspectives from women participants. SA Journal of Human Resource Management/SA Tydskrif vir Menslikehulpbronbestuur, 13(1), Art. \#659, 11 pages. http://dx.doi.org/10.4102/sajhrm.v13i1.659, for more information.

hub located in the city of Port Elizabeth and was chosen due to researcher familiarity.

\section{Entree and establishing researcher roles}

Given that the study involved two universities, ethics approval was sought from and granted by both universities. Permission was also sought from participants who were informed of the purpose of the research and how data generated will be used for teaching purposes and writing journal articles.

\section{Sampling and participants}

Convenience sampling (Cohen, Manion \& Morrison, 2007, p. 114) was used for this research and allowed the researcher to identify 'available and accessible' participants for the study. The hosting South African university served as a strategic hub from which potential participants could be sampled. Inclusion and exclusion criteria had to be adopted. All participants had be registered distance learners with the South African university. Participants were excluded if they did not meet this criterion. A total of 25 women participants took part in the research; Table 2 summarises the characteristics of the 30 participants used as part of this study.

\section{Data collection methods}

The interviews were recorded and transcribed verbatim. In addition to this, notes were made to accompany the recording. Given that participants in the study were studying and working, a strategic hub in the form of a leading distance learning university campus was important in accessing the sample. Participants had to be recognised 
by law of being previously disadvantaged either by race or by gender (Cottrell, 2005). Participants were excluded if they did not meet this criterion. Participants were approached and informed of the goals of the study and consent asked for their participation. Upon agreeing, participants filled in a consent form and their confidentiality was guaranteed. Since the study involved two universities, geographically separated, ethical clearance was applied for at both institutions and granted. In addition, participants in the research had to give consent before taking part in the research.

\section{Recording of the data \\ Data analysis}

The interviews were exported into QSR International's NVivo 9, a data analysis and management software package useful when dealing with a lot of text, graphic, audio and video data (Reuben \& Bobat, 2014). A data analysis procedure based on three levels of meaning making as adopted in

TABLE 2: The characteristics of the respondents.

\begin{tabular}{|c|c|c|c|c|}
\hline Pseudonym & Occupation & Age & $\begin{array}{c}\text { Work } \\
\text { experience }\end{array}$ & Race group \\
\hline Jennifer & Bank teller & 29 & 5 & Black \\
\hline Mary & Administrator & 27 & 8 & Black \\
\hline Nandipha & Store assistant & 22 & 2 & Black \\
\hline Busi & Teacher & 44 & 10 & Black \\
\hline Nwabisa & Accountant & 30 & 8 & Black \\
\hline Michelle & Engineer & 31 & 9 & Black \\
\hline Rachel & Secretary & 30 & 5 & Black \\
\hline Helen & Teacher & 27 & 2 & Mixed race \\
\hline Unathi & $\begin{array}{l}\text { Unemployed } \\
\text { (volunteering) }\end{array}$ & 23 & 2 & Black \\
\hline Glenda & Police officer & 49 & 7 & Black \\
\hline Rayline & Clerk & 30 & 5 & Mixed race \\
\hline Tshepiso & $\begin{array}{l}\text { Unemployed } \\
\text { (volunteering) }\end{array}$ & 23 & 2 & Black \\
\hline Sarah & Clerk & 29 & 5 & Black \\
\hline Bridget & $\begin{array}{l}\text { Human resources } \\
\text { officer }\end{array}$ & 52 & 15 & Black \\
\hline Kate & Teacher & 25 & 9 & Mixed race \\
\hline Zandile & $\begin{array}{l}\text { Quality assurance } \\
\text { officer }\end{array}$ & 38 & 4 & Black \\
\hline Patience & $\begin{array}{l}\text { Unemployed } \\
\text { (volunteering) }\end{array}$ & 23 & 2 & Mixed race \\
\hline Nomusa & Social Work & 29 & 5 & Black \\
\hline Siphokazi & Secretary & 25 & 8 & Black \\
\hline Zama & Teacher & 38 & 15 & Black \\
\hline Nkulie & $\begin{array}{l}\text { Human resources } \\
\text { officer }\end{array}$ & 35 & 5 & Black \\
\hline Anna & Sales officer & 25 & 3 & Black \\
\hline Becky & Accountant & 24 & 2 & Mixed race \\
\hline Sherry & Clerk & 25 & 3 & Mixed race \\
\hline Jenny & $\begin{array}{l}\text { Public relations } \\
\text { officer }\end{array}$ & 29 & 4 & Mixed race \\
\hline
\end{tabular}

previous research was used (e.g. Chinyamurindi, 2012; McCormack, 2000). Table 3 represents the stages of the levels of meaning making adopted in the data analysis.

Level 1 was helpful in developing a good understanding of the career development experience of each participant. This was done by rereading each interview and listening to audio recordings. Such a process allowed for the identification of 'markers' in the stories (McCormack, 2000, p. 282) and answering the following question about each interview: 'What kind of story is this?' (Thornhill, Clare \& May, 2004, p. 188). Level 2 was achieved through classifying responses from participants into meaningful categories (Nachmias \& Nachmias, 1996). Finally, in level 3, the researcher analysed the content of the gathered narrative accounts and themes (McCormack, 2000). This was done by identifying themes and using quotes based on consistencies across participant stories (Rhodes, 2000).

\section{Strategies to ensure data quality and reporting}

To ensure data quality, four steps were taken. Firstly, initial interview questions were pre-tested with a sample of 10 students (non-participants) who fit the same profile as those interviewed in the main part of the research. Secondly, to ensure credible data, all interview data were recorded and transcribed verbatim within 24 hours. Thirdly, after transcription data, participants were emailed a copy of the transcription to verify if this was accurate as per the interview. Finally, before and during the study, reflexivity was conducted to safeguard objectivity and avoid researcher bias (Lewin, Taylor \& Gibbs, 2005); this was also done to ensure sensitivity with regard to how data is collected, analysed and represented (Mays \& Pope, 2000). In doing so, comprehensive notes were taken at all key stages of the research for additional depth and quality.

\section{Research results and findings}

Based on the data analysis, various factors emerged that portray a picture of the factors that contribute to and impede the career success of women (see Figure 1) and these are discussed next. Table 4 presents a summary of the factors that contribute to career success and Table 5 presents those factors that impede career success.

\section{Contributing factors}

Table 4 presents the specific factors contributing to the success of women. Participants considered career success to be influenced by the intersection between individual factors with individual characteristics and contextual factors such

TABLE 3: Data analysis procedure.

\begin{tabular}{ll}
\hline Level of meaning making & Description \\
\hline 1 & Each interview is written as a brief vignette. Thereafter, each vignette is then developed into a longer narrative about each participant. \\
2 & $\begin{array}{l}\text { Narrative themes are then conveyed by participants and their experience of career development. Thereafter, preliminary themes are then } \\
\text { compared across participants. }\end{array}$ \\
3 & An analysis of the themes from cross-case comparison begins and illustrating quotes and stories are used. \\
\hline
\end{tabular}


as presence of support structures, interventions such as employment equity and affirmative action and educational attainment.

Educational attainment refers to the quest for professional attainment and receiving recognition for this. Most participants cited the recognition and responsibility that comes with a professional title. Salient titles included being 'an accountant', 'a lawyer' and 'a psychologist'. Thus, educational attainment was viewed as a contributing factor towards individual career success as this led to the attainment of an 'expert' status.

An example is given from one participant's story. Jennifer was working as a bank teller and also studying via distance learning for an accounting degree. Her wish was to use her accounting qualification to move away from being a bank teller to becoming a 'chartered accountant' within the bank. During the interview she painted a picture of how she did not enjoy the 'routine' and mundane activities that came with being a teller. For her, being a 'chartered accountant' was the

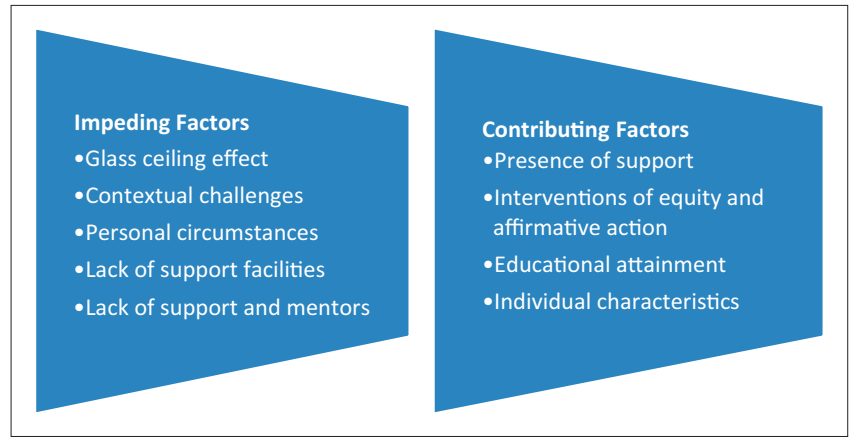

Source: Author's own creation

FIGURE 1: Factors contributing to and impending career success. goal to be attained although she did not like the journey leading to this. In her narration, educational attainment was to contribute to her attaining 'expert' status:

'It's about being an expert at what I do and people turning to me because of this expertise. If that happens then I consider myself as successful.' (Jennifer, bank teller, black, 29 years old)

Another participant's narrative echoed the same sentiments. Mary was head hunted to work in an administrative role for a new bank. This role entailed 'challenging' tasks. Mary enrolled to study via distance learning so as to improve her chances of being promoted in the bank. Like Jennifer, Mary also made reference to professional attainment and recognition as an evaluation of career success:

'I would love to be good and be an expert in something. In my company I am becoming that within sales and customer relationship management. I feel I am going somewhere and I am getting the recognition of an expert.' (Mary, administrator, black, 27 years old)

Attaining an education appears to open doors for participants; their individual career development is subsequently viewed as linked to career success. This was manifest mainly through further study by distance learning and taking up opportunities for further career development. Participants did not see themselves as being stagnant, but as constantly improving themselves. The quest for growth was actuated through the need for further study and also taking part in organisational training interventions to improve individual skills and qualifications.

From the interviews, the presence of support structures provided a platform from which to achieve career success. Such support structures appear to be routed within

TABLE 4: Summary of factors perceived to contribute to career success.

\begin{tabular}{|c|c|c|}
\hline Factor & Meaning & Example quotes \\
\hline \multirow[t]{2}{*}{ The presence of support } & \multirow{2}{*}{$\begin{array}{l}\text { The contributing influence of individuals, family, community } \\
\text { members and organisational members towards career } \\
\text { development. Support came in various forms: material and } \\
\text { non-material support. }\end{array}$} & $\begin{array}{l}\text { 'My family has sacrificed a lot for me to be where I am. Paying my fees, my } \\
\text { subsistence and even at my lowest moments of dealing with job loss. I am here } \\
\text { really because of them.' - Rachel }\end{array}$ \\
\hline & & $\begin{array}{l}\text { 'South Africa is really about who you know. I am here today because of my } \\
\text { connections and friends. There is no way as a black person and also a woman I } \\
\text { would have succeeded without these people. I am a success today because of such } \\
\text { support opening doors for me career wise that were shut.' - Rayline }\end{array}$ \\
\hline \multirow[t]{3}{*}{$\begin{array}{l}\text { Interventions of equity and } \\
\text { affirmative action }\end{array}$} & \multirow[t]{3}{*}{$\begin{array}{l}\text { The role edict and legislative laws introduced to give previously } \\
\text { disadvantaged groups an opportunity for advancement. These } \\
\text { included internships, jobs for designated groups and the filling } \\
\text { of necessary quotas in organisations. }\end{array}$} & $\begin{array}{l}\text { 'I was really at the right place at the right time. I got a call from a recruiting } \\
\text { company after years of job hunting and being rejected. Their client was looking } \\
\text { in simple terms for a black person to join them. Though I want people to } \\
\text { acknowledge my competencies first, my race got me the one job that has made } \\
\text { me what I am.' - Sherry }\end{array}$ \\
\hline & & $\begin{array}{l}\text { 'I applied for internship meant for previously disadvantaged people, I got in and } \\
\text { that's all I wanted; to get in. What has happened to this point was due to that one } \\
\text { opportunity of getting in the system.' - Nkulie }\end{array}$ \\
\hline & & $\begin{array}{l}\text { 'I want people especially those incorporate South Africa to embrace my being a } \\
\text { woman and being black. So many opportunities exist out there especially for black } \\
\text { women, that's all I needed to make an impact.' - Nwabisa }\end{array}$ \\
\hline \multirow[t]{2}{*}{ Educational attainment } & \multirow[t]{2}{*}{$\begin{array}{l}\text { Quests around getting a qualification or rising to an expert } \\
\text { status. }\end{array}$} & $\begin{array}{l}\text { 'Getting my education degree made me get promoted; I am now a senior } \\
\text { educator. I think studying further like I am doing will open further doors for career } \\
\text { advancement.' - Busi }\end{array}$ \\
\hline & & $\begin{array}{l}\text { 'I needed to do some professional courses as a promotion was due at work. } \\
\text { Completing these courses not only made me get a promotion but gave me } \\
\text { an expert role of being quality assurance guru. I must live up to my titles and } \\
\text { qualifications to continue being a success.' - Zandile }\end{array}$ \\
\hline \multirow[t]{2}{*}{ Individual characteristics } & \multirow[t]{2}{*}{$\begin{array}{l}\text { Specific individual attributes and activities and their role of } \\
\text { career development. }\end{array}$} & $\begin{array}{l}\text { I am a testimony of the fruits of hard work and this why I am successful not } \\
\text { because I am black or a woman but because I worked hard for what I have } \\
\text { today.' - Nomusa }\end{array}$ \\
\hline & & $\begin{array}{l}\text { 'There is no substitute for persistence and determination. These are traits I was } \\
\text { taught from a young age and have used to shape my life. These have me what } \\
\text { I am.' - Kate }\end{array}$ \\
\hline
\end{tabular}


community and were used for various activities. For instance, Bridget attributes her success to her family who have 'stood by her even when she has made some bad decisions'. It appears that the proximity of family to Bridget made her trust them and hence she could turn to them for support. Others like Glenda cited the role of friends as the factor contributing to her success. In her narration, Glenda discussed gender and race:

'Truth be told there is no place for a woman let alone a black woman in the corporate world. So we decided to make a way for ourselves as sisters. One of my friends works for a reputable motor manufacturing company here in Port Elizabeth, she got a good job. She then supported me through mentoring and even talking to her superiors so I can get in the system. Now that I am here and consider myself successful, I must help the next black sister also struggling to get in. That's how we should do it, sisters doing it for themselves.' (Glenda, police officer, black, 49 years old)

Interventions targeted at redress were also attributed to be influential in contributing to the success of women. The quotes by Sherry, Nkulie and Nwabisa in Table 4 illustrate this. Such interventions, like the presence of support, provided a platform from which women could enter a workplace that has barriers. A final contributing factor to success were those qualities specific to the individual such as being hardworking and persistent despite challenges. Interestingly, some of the women also brought up race and gender not as proxies to their success, but rather attributing influence to individual characteristics and qualities such as hard work, as in the case of Nomusa (see Table 4).

This study also found factors that revealed barriers affecting career success of women; illustrating quotes are presented in Table 5.

\section{Impeding factors}

Like factors contributing towards career success, those factors that impede career success were specific to the individuals and also contextual. For instance, participants like Nwabisa cited contextual challenges as influencing her career development and subsequent framing of career success due to perceptions of the role of a woman in society:

'I am from rural Cofimvaba and you can see people in my community are not supportive to the career development of women. This can be due to thinking that our role as women is just to have children, stay in the kitchen and fend for the children. To an extent because of this prevailing attitude, girls like me will never be anything and that is sad and limiting.' (Nwabisa, accountant, black, 30 years old)

Contextual challenges appear to also trickle into personal challenges and impede career success. Notably, personal circumstances such as poverty were salient. However, participants such as Zama (illustrated in Table 5) cited personal challenge pertaining to the need for balance between duties of being a mother and wife and also a career woman as impeding her career success. Linked to this were also barriers such as the glass ceiling effect, also cited as common in the workplace. Continual reference was made by participants to the privileged position of men ahead of women and the preferential treatment they receive in society.

The quotes from Becky and Anna in Table 5 bring into focus the existence of prejudice against women in corporate South Africa.

\section{Role of distance learning on individual career development}

In the framing of career success, the role of distance learning appears to serve as a utility function of advancing individual career development en route to the experience of career success. Generally, participants cited mixed emotions towards studying by distance:

'Being a distance learner has helped me realise my career goal of finally getting a tertiary qualification. This means that I can be

TABLE 5: Summary of factors perceived to impede career success.

\begin{tabular}{|c|c|c|}
\hline Factor & Meaning & Example quotes \\
\hline \multirow[t]{2}{*}{ Glass ceiling } & $\begin{array}{l}\text { Barriers that stop the career advancement of women to } \\
\text { higher positions. These could be through organisational } \\
\text { policy, human influenced tactics and sabotage by others. }\end{array}$ & $\begin{array}{l}\text { 'Every day is a struggle at work, two steps forward and three steps backward. I feel } \\
\text { as if the workplace is a male dominated world and to my colleagues there is no place } \\
\text { for a woman. Promotions are not coming my way and there are no opportunities for } \\
\text { advancement. On the other hand, male colleagues on the same salary bracket as me } \\
\text { are soaring.' - Anna }\end{array}$ \\
\hline & & $\begin{array}{l}\text { 'It's a man's world in corporate South Africa, an all boys club. You remain static if you } \\
\text { do everything by the book. Break loose for your advancement else you are going } \\
\text { nowhere.' - Becky }\end{array}$ \\
\hline \multirow[t]{2}{*}{ Contextual challenges } & $\begin{array}{l}\text { Social and economic challenges and their role on individual } \\
\text { career development. }\end{array}$ & $\begin{array}{l}\text { 'Growing up in the townships of Motherwell, one must contend with poverty, high } \\
\text { crime and growing unemployment. Every male and female must face these challenges, } \\
\text { for the girl child your career advancement is affected due to these challenges.' - } \\
\text { Nandipha }\end{array}$ \\
\hline & & $\begin{array}{l}\text { 'There is no money to go to good schools. You end up in schools that are under- } \\
\text { resourced and bad facilities. While on the other side of town our White friends } \\
\text { have everything made for them. It's tough being a black person in South Africa, our } \\
\text { problem lies in where we are from. Change our context you change our lives and we } \\
\text { to can be a success.' - Busi }\end{array}$ \\
\hline Personal circumstances & $\begin{array}{l}\text { Challenges that exist around personal circumstances. These } \\
\text { include: dealing with family responsibilities and work-life } \\
\text { balance. }\end{array}$ & $\begin{array}{l}\text { 'I am a wife, a mother and career person. The challenge is to juggle around these } \\
\text { roles and seek a balance. That to me is a challenge, if I advance to a senior position, } \\
\text { it means compromising my motherly and wife duties. From my culture I would have } \\
\text { failed if I neglect my husband and kids.' - Zama }\end{array}$ \\
\hline \multirow[t]{2}{*}{$\begin{array}{l}\text { Lack of resources and } \\
\text { support facilities }\end{array}$} & $\begin{array}{l}\text { The absence of material and non-material artefacts and their } \\
\text { influence on career development. }\end{array}$ & $\begin{array}{l}\text { 'I think I would have finished my degree if I had face to face contact. Distance learning } \\
\text { is tough and the lack of support has affected my career advancement. No degree } \\
\text { means no promotion.' - Patience }\end{array}$ \\
\hline & & $\begin{array}{l}\text { 'No positive role models exist for me. I watched a movie once and heard a line that } \\
\text { goes - it's hard to soar with the eagles when surrounded by turkeys. I think things will } \\
\text { be different career wise and my life if I had a good support mechanism.' - Sarah }\end{array}$ \\
\hline
\end{tabular}


taken seriously in my organisation. However, it's not easy. It's a struggle of balancing between work, personal life and study. Sometimes I don't know how I cope.' (Siphokazi, secretary, black, 25 years old)

Furthermore, distance learning appeared to also meet a pragmatic need for participants as a cost-effective mode of study in comparison to full-time studying:

'Distance learning is really cheap and I guess with my financial situation this is not only important but a priority as I want to reach my career goals.' (Michelle, engineer, black, 31 years old)

Finally, distance learning fit well with seeking a balance in life. It would appear that career success was not just an experience of accomplishment in terms of study and also working life, but also about seeking a balance between all these:

'I do not want to be a successful person career wise and yet a failure to my family. Distance learning is flexible so I can still be a mother and a wife while also pursuing my own ambitions.' (Zama, teacher, black, 38 years old)

Distance learning emerged as an enabler of the framing of career success through skills acquisition and attaining professional qualifications. Thus, distance learning was a tool to achieving career success.

\section{Discussion \\ Outline of the findings}

The purpose of this study was to identify the specific factors that influence the career success of women distance learners within a South African context. Two types of factors emerged. Contributing factors are those factors that encourage the career development of women and subsequently their framing of career success. Impeding factors are those that act as barriers towards career development and subsequently affect an individual's career success.

Firstly, contributing factors were identified and further grouped into two categories:

- Individual specific factors such as drive, motivation and individual strategies leading to career success. For example, the quest for educational and professional attainment.

- Contextual factors such as the presence of support and the influence of policies and legislative mandates aimed at redress.

Secondly, impeding factors are also grouped into two categories:

- Individual specific factors around personal circumstance and challenges. These challenges include lack of resources and support facilities, work-life balance and attending to family responsibilities.

- Contextual factors include factors in the organisation and factors in the macro environment.

Both contributing and impeding factors that influence career success include individual and contextual factors. Generally, these two factors are the same as the factors that influence career development as theorised within the Systems Theory Framework (Patton \& McMahon, 2006). This study has illustrated their role in the experience of career success amongst a sample of previously disadvantaged women in South Africa.

\section{Relating main findings to literature}

The findings of this research appear to support some general factors that contribute to or impede the career success of women. There is support of previous studies that showed factors that contribute to career success such as support structures available to women (Doubell \& Struwig, 2014; Ravindaran \& Baral, 2013), individual specific attributes of women (Ip, 2011; Riordan \& Louw-Potgieter, 2011) and the influence of organisational and professional development efforts (Bombuwela \& Chamaru, 2013; Sasithornsaowapa, 2013; Teo, Lord \& Nowak, 2014). In essence, these factors were acknowledged by participants in this study to inform career development positively and to aid individual progress. The interaction of these factors appears to support the idea of career development as shaped by the interaction between individual and contextual factors (Ozbilgin, 2011; Patton \& McMahon, 2006).

With regard to impeding factors, this research supports previous findings that found lack of support structures (Maxwell \& Ogden, 2011; Pheko, 2014), relationships and work-life balance (Evers \& Sieverding, 2014; Maxwell \& Ogden, 2011; Pheko, 2014; Raburu, 2015; Yet-Mee, Peng \& Yin-Fah, 2013). Further, participants in this research cited the role of economic and social factors (Austin \& Cilliers, 2011) as working together in shaping their career development. Narratives of participants illustrated the dynamic interaction between the person and their environment (Patton \& McMahon, 2006). This interaction was also complex as is manifest through the identified factors that impede career success illustrated in the participants' stories. Due to the nature of this complex and dynamic interaction as found in this research, this implies that career development is a nonlinear process and one that is difficult to predict.

In dealing with the factors that impede career success, women also engage in a process of self-management (Savickas, 2011) in finding resolutions to their quest for career development. One way this was found to happen in this study was through lifelong learning (Braimoh, 2010), which brings into focus the role of distance learning. Similar to previous studies (Pheko, 2014), the role of education is highlighted in this study as aiding the career success of women. Distance education based on these participants' views occupied a pragmatic function that cannot be divorced from individual needs or the circumstances surrounding their life situation.

The study makes a number of contributions. Firstly, in studying the career success of women distance learners, career development is portrayed as a complex process that does 
not follow a hierarchical approach as believed in traditional career theories. Thus, the findings of this research negate theorising espoused in career theories of career development as being reductionist and fragmented by viewing a holistic perspective of the lived experience (Joo \& Park, 2010; Price, 2009). Secondly, this study contributes to our understanding of career success especially in a South African context (Koekemoer, 2014) by using an 'understudied' yet important sample group in South Africa: previously disadvantaged individuals (Schreuder \& Coetzee, 2012, p. 2). Based on this study, solutions and interventions may be proposed, helping to expand understanding of career development (Savickas, 2011).

Thirdly, this study illustrates how career development processes are facilitated within a distance learning context (Burgess \& Russell, 2003), including the contributing and impeding factors that affect career success amongst this cohort of the South African population. These include: financial constraints, the failure to be accepted into full-time universities, poor high school matriculation and individual circumstance, thus supporting previous studies (Lemmer, 2009; Pityana, 2009). In essence, distance education assisted the career development process with the individual acquiring a qualification or the skills to support this. Distance education also created a space not just for acquiring an education, but for mobility away from a life of disadvantage to a better one considering the individual situation and background in South Africa. This study has illustrated how these processes happen within a distance education context. Finally, this study has answered calls for studies investigating career experiences through the subjective lens (Chudzikowski, 2012) and seeking to understand career development not as a static, but as a dynamic process (Hirshi, 2011).

\section{Practical implications}

Given that the majority of the participants in this study were career women, a practical implication from this study could be to devise interventions into how women balance life roles with not only their studies, but also employment. The focal point here should be on helping women not only through education, but also career development. This can also be important and prudent in informing policy efforts on a grand scale, especially amongst individuals working and studying at the same time. The desired goal here should not only be inclusion and access to education, but also the management of individual success through career development - especially for those previously disadvantaged in South Africa.

Another practical implication for this study is around the issue of striving for balance between study, work and personal and social commitments. There appears to be a paradox here. On one hand, this balance is needed and distance learning allows for it. However, it appears that maintaining such a balance places a great strain on the individual and a possible stumbling block. Career counsellors can assess their client's commitment towards this balance by drawing on the narratives (as illustrated in this study) and ascertaining practical interventions around such an important construct. One useful way is to offer training courses targeted for distance learners in which aspects of life-balance are part of the training. In addition to this, and specifically with distance learners, it may be helpful to make those intending to enrol via distance learning aware of some of the potential challenges accompanying their enrolment, including striving for balance in the lived experience.

Trainers and organisational development practitioners can use narratives (as done in this research) for material development and training targeted for women. This can help relate practical and contextual real-life stories to concepts that can be viewed as abstract. In turn, this may not only inspire, but also help in proposing interventions that women can relate to. Given that the narratives and stories used in this research are context specific, this can allow trainers the opportunity to relate to not only the lives of career women, but also the performative dimension of careers and its complexity. This allows for trainers to identify with lives of career women used in this research as role models. The thinking here is that through teaching and learning from the lives of career women, one can re-story one's life.

\section{Limitations of the study}

Although this study was helpful in understanding the factors that influence career success amongst a sample of women distance learners in South Africa, some limitations can be flagged. The sample size was not representative of the population of either previously disadvantaged individuals or women in South Africa. From the sample, only black and mixed race women took part in the research. This subsequently affects issues of generalisability. Furthermore, the participants were all distance learners from only a single province in South Africa (Eastern Cape). This again raises issues of generalisability from a geographical and modal system of education perspective. Furthermore, given the subjective nature of the study and that interpretation of participant data into themes was also based on the researcher's influence, the research is not bias free.

\section{Suggestions for future research}

Future research could compare factors that influence career success across geographical locations and also include the full-time mode of learning. Furthermore, future research can also include male participants in its investigation of career success. All this can be done as a basis of comparison in relation to the findings of this research. The impact of the glass ceiling effect emerged as a finding in this research as also in previous research (e.g. Koekemoer, 2014; Pheko, 2014). Clearly there is a need to further unpack this concept. Future research could use various approaches and techniques in understanding the glass ceiling effect. These may include a quantitative survey approach in ascertaining the influence of the glass ceiling effect on objective and subjective outcomes of career success such as career satisfaction or job satisfaction. Also, a longitudinal study tracing the experiences of women 
and their career development can provide useful insights on phenomena such as career success.

\section{Conclusion}

This study places importance on understanding the role and influence of context and individual agency on career development processes and experiences such as career success. Thus, this study has highlighted factors that may contribute to or impede career success including the complexity of these on career construction in South Africa for women. The findings provide a basis for future research appealing to the academic and practitioner press, especially in using an 'understudied' (Schreuder \& Coetzee, 2012, p. 4) yet important population cohort given the agenda of economic redress, social justice and equity. This forms a basis for theoretical and practical interventions.

\section{Acknowledgements}

An earlier version of this article was presented at the 2nd International Conference on Human Resources Management and the Management of Organisations in Africa Conference, hosted by Nottingham Business School (United Kingdom) in September 2012. The author thanks attendees to this conference for their constructive feedback.

\section{Competing interests}

The author declares that he has no financial or personal relationships that may have inappropriately influenced him in writing this article.

\section{References}

Abele, A.E., \& Spurk, D. (2009). How do objective and subjective career success interrelate over time? Journal of Occupational and Organizational Psychology, 82, 803-824. http://dx.doi.org/10.1348/096317909X470924

Adamson, S.J., Doherty, N., \& Viney, C. (1998). The meanings of career revisited: Implications for theory and practice. British Journal of Management, 9(4), 251-259. http://dx.doi.org/10.1111/1467-8551.00096

Asuquo, P.N., \& Inaja, E. (2013). Fostering sustainable career development and employability among young people in the changing world of work: Employers' perspective. Procedia - Social and Behavioral Sciences, 84, 1492-1499. http:// dx.doi.org/10.1016/j.sbspro.2013.06.778

Austin, K., \& Cilliers, F. (2011). The psychometric relationship between career thinking and salutogenic functioning amongst unemployed adults. South African Journal of Industrial Psychology, 37(1), 1-11. http://dx.doi.org/10.4102/sajip. v37i1.969

Baruch, Y. (2006). Career development in organisations and beyond: Balancing traditional and contemporary viewpoints. Human Resource Management Review, 16, 125-138. http://dx.doi.org/10.1016/j.hrmr.2006.03.002

Bombuwela, P.M., \& Chamaru, D.A.A. (2013). Effects of glass ceiling on women career development in private sector organizations - Case of Sri Lanka. Journal of Competitiveness, 5(2), 3-19. http://dx.doi.org/10.7441/joc.2013.02.01

Booysen, L.A.E., \& Nkomo, S.M. (2010). Gender role stereotypes and requisite management characteristics: The case of South Africa. Gender in Management: An International Journal, 25(4), 285-300. http://dx.doi. org/10.1108/17542411011048164

Booysen, S. (1999). Towards more feminine business leadership for the 21st century: A literature overview and a study of the potential implications for South Africa. South African Journal of Labour Relations, 23(1), 31-54.

Braimoh, D. (2010). Revisiting lifelong learning for quality improvement in ODL institutions in Africa. Africa Education Review, 7(2), 229-243. http://dx.doi.org/ $10.1080 / 18146627.2010 .515420$

Burgess, J.R.D., \& Russell, J.E.A. (2003). The effectiveness of distance learning initiatives in organizations. Journal of Vocational Behavior, 63(2), 289-303. http:// dx.doi.org/10.1016/S0001-8791(03)00045-9

Chinyamurindi, W.T. (2012). An investigation of career change using a narrative and story-telling inquiry. South African Journal of Human Resource Management, 10(2), 1-11. http://dx.doi.org/10.4102/sajhrm.v10i2.447
Chudzikowski, K. (2012). Career transitions and career success in the 'new' career era. Journal of Vocational Behavior, 81(2), 298-306. http://dx.doi.org/10.1016/j. jvb.2011.10.005

Chudzikowski, K., \& Mayrhofer, J. (2011). In search of the blue flower? Grand social theories and career research: The case of Bourdieu's theory of practice. Human Relations, 64(1), 19-36. http://dx.doi.org/10.1177/0018726710384291

Coetzee, M., \& Gunz, M. (2012). Careers and retention of staff in the 21st century world of work: Introduction to the special edition. South African Journal of Human Resource Management, 10(2), 1-4. http://dx.doi.org/10.4102/sajhrm. v10i2.505

Coetzee, M., \& Schreuder, A.M.G. (2009). Using the Career Orientations Inventory (COI) for measuring career orientations in the South African organisational context. South African Journal of Industrial Psychology, 35(1), 1-13. http://dx.doi. org/10.4102/sajip.v35i1.806

Cohen, L., Manion, L., \& Morrison, K. (2007).Research methods in education. (6th edn.). London: Routledge-Falmer.

Cottrell, R. (2005). South Africa: A state of apartheid. New York, NY: ChelseaHouse.

Czakan, P. (2006). Retention of workers in telecommunications. Unpublished MBA thesis, Graduate School of Business. Cape Town: University of Cape Town.

De Bruin, W. (2000). Women: A growing economic force: An F and T Finance Week Feature. Finance Week, 22 September, 37-47.

Department of Education. (2010). Education Statistics in South Africa 2009. Pretoria: Author

Department of Higher Education and Training. (2013). White paper for post-schoo education and training: Building an expanded, effective and integrated post-school system. Retrieved January 13, 2015, from http://www.dhet.gov.za/SiteAssets/ Latest $\% 20$ News/White $\% 20$ paper $\% 20$ for $\% 20$ post-school $\% 20$ education $\% 20$ and\%20training.pdf

Doubell, M., \& Struwig, M. (2014). Perceptions of factors influencing the career success of professional and business women in South Africa. South African Journa of Economic Management Sciences, 17(5), 531-543.

Dries, N., Pepermans, R., \& Rypens, L. (2009). Development and validation of an objective intra-organizational career success measure for managers. Journal of Organizational Behavior, 30, 543-560. http://dx.doi.org/10.1002/job.564

Edwards, P. (2011). Message from the new editor-in-chief. Human Relations, 65(1), 3-4. http://dx.doi.org/10.1177/0018726711428110

Evers, A., \& Sieverding, M. (2014). Why do highly qualified women (still) earn less? Gender differences in long-term predictors of career success. Psychology of Women Quarterly, 38(1), 93-106. http://dx.doi.org/10.1177/0361684313498071

Fraenkel, J.R., \& Wallen, N.E. (2006). How to design and evaluate research in education. New York, NY: McGraw-Hill.

Gattiker, U.E., \& Larwood, L. (1986). Subjective career success: A study of managers and support personnel. Journal of Business and Psychology, 1, 78-94. http:// dx.doi.org/10.1007/BF01018805

Greenhaus, J.H., Parasuraman, S., \& Wormley, W.M. (1990). Effects of race on organizational experiences, job performance evaluations, and caree outcomes. Academy of Management Journal, 33(1), 64-86. http://dx.doi. org/10.2307/256352

Guba, E.G., \& Lincoln, Y.S. (1994). Competing paradigms in qualitative research. In N.K. Denzin, \& Y.S. Lincoln (Eds.), Handbook of qualitative research (pp. 105-117). Thousand Oaks, CA: Sage.

Hallebone, E., \& Priest, J. (2009). Business and management research: Paradigms and practices. New York, NY: Palgrave Macmillan.

Heslin, P.A. (2005). Conceptualizing and evaluating career success. Journal of Organizational Behavior, 26, 113-136. http://dx.doi.org/10.1002/job.270

Hirshi, A. (2011). Career-choice readiness in adolescence: Developmental trajectories and individual differences. Journal of Vocational Behavior, 79, 340-348. http:// dx.doi.org/10.1016/j.jvb.2011.05.005

Ip, N. (2011). Career development for women scientists in Asia. Neuron, 70, 10291032. http://dx.doi.org/10.1016/j.neuron.2011.06.008

Joo, B.K., \& Park, S. (2010). Career satisfaction, organizational commitment, and turnover intention: The effects of goal orientation, organizational, learning culture and developmental feedback. Leadership \& Organization Development Journal, 31(6), 482-500. http://dx.doi.org/10.1108/01437731011069999

Judge, T.A., Cable, D.M., Boudreau, J.W., \& Bretz, R.D. (1995). An empirical investigation of the predictors of executive career success. Personnel Psychology, 48, 485-517. http://dx.doi.org/10.1111/j.1744-6570.1995.tb01767.x

Khapova, S.N., \& Arthur. M.B. (2011). Interdisciplinary approaches to contemporary career studies. Human Relations, 64(1), 3-17. http://dx.doi. org/10.1177/0018726710384294

Koekemoer, E. (2014). An explorative study on factors influencing the career success of management employees. South African Journal of Industrial Psychology, 40(2), 1-10. http://dx.doi.org/10.4102/sajip.v40i2.1204

Lemmer, E.M. (2009). Empowerment of women students through educational achievement: A narrative inquiry. African Education Review, 6(1), 80-95. http:// dx.doi.org/10.1080/18146620902857319

Lewin, A., Taylor, C., \& Gibbs, G.R. (2005).What is qualitative data analysis (QDA)? Retrieved January 13, 2015, from http://onlineqda.hud.ac.uk/Intro_QDA/what is_qda.php

Mahlomaholo, S.M.G. (2011). Gender differentials and sustainable learning environments. South African Journal of Education, 31, 312-321.

Maree, J.G. (2010). Career counselling: Methods that work. Cape Town: Juta. 
Maree, J.G. (2014). Career construction with a gay client: A case study. British Journal of Guidance \& Counselling, 42, 436-449. http://dx.doi.org/10.1080/03069885.2 014.886670

Maree, J.G. (2015). Career construction counseling: A thematic analysis of outcomes for four clients. Journal of Vocational Behavior, 86, 1-9. http://dx.doi. org/10.1016/j.jvb.2014.10.001

Maxwell, G., \& Ogden, S. (2011). Career development of female managers in retailing: Inhibitors and enablers. Journal of Retailing and Consumer Services, 13, 111-120. http://dx.doi.org/10.1016/j.jretconser.2005.08.010

Mays, N., \& Pope, C. (2000). Assessing quality in qualitative research. British Medical Journal, 320, 50-52. http://dx.doi.org/10.1136/bmj.320.7226.50

McCormack, C. (2000). From interview transcript to interpretative story: Part 1. Viewing the transcript through multiple lenses. Field Methods, 12(4), 282-297. http://dx.doi.org/10.1177/1525822X0001200402

Mkhize, M., \& Msweli, P. (2011). The impact of female business leaders on the performance of listed companies in South Africa. South African Journal of Economics Management, 14(1), 1-7.

Moletsane, R., \& Reddy, V. (2008). An assessment of the participation of women in set industry for Department of Science and Technology. Retrieved June 09, 2013, from
http://www.hsrc.ac.za/research/output/outputDocuments/5505_Moletsane_ http://www.hsrc.ac.za/research/output/o
Assessmentoftheparticipationofwomen.pdf

Nachmias, F.C., \& Nachmias, D. (1996). Research methods in the social sciences. (5th edn.). New York, NY: Worth Publishers.

Ndzube, F. (2013). The relationship between career anchors and employability Unpublished master's dissertation, Department of Industrial and Organisational Psychology. Pretoria: University of South Africa.

Nefcorp. (2005). National empowerment fund glossary. Retrieved June 12, 2013, from http://www.nefcorp.co.za/glossary.asap

Ng, T.W.H., Eby, L.T., Sorensen, K.L., \& Feldman, D.C. (2005). Predictors of objective and subjective career success: A meta-analysis. Personnel Psychology, 58, 367-408. http://dx.doi.org/10.1111/j.1744-6570.2005.00515.x

Nicholson, N. (2000). Motivation-selection-connection: An evolutionary model of career development. In M. Peiperl, M. Arthur, R. Goffee, \& T. Morris (Eds.), Caree frontiers: New concepts of working life (pp. 54-75). Oxford: Oxford University Press.

O'Neil, D., \& Bilimoria, D. (2005). Women's career development phases: Idealism, endurance, and reinvention. Career Development International, 10, 168-188. $\mathrm{http}: / / \mathrm{dx}$.doi.org/10.1108/13620430510598300

Oosthuizen, R.M., Coetzee, M., \& Mntonintshi, F. (2014). Investigating the relationship between employees' career anchors and their psychosocial employability attributes in a financial company. South African Journal of Human Resourc Management, 12(1), 1-10. http://dx.doi.org/10.4102/sajhrm.v12i1.650

Ozbilgin, M. (2011). Continuity and change: Improving our service to the BJM community and moving towards contextual studies of management. British Journa of Management, 22, 1-3. http://dx.doi.org/10.1111/j.1467-8551.2011.00739.x

Patton, W., \& McMahon, M. (2006). Career development and systems theory. (2nd edn.). Pacific Grove, CA: Brooks/Cole.

Pheko, M.M. (2014). Batswana female managers' career experiences and perspectives on corporate mobility and success. South African Journal of Human Resource Management, 12(1), 1-11. http://dx.doi.org/10.4102/sajhrm.v12i1.445

Pityana, N. (2009). Open distance learning in the developing world: Trends, progress and challenges. Keynote address at 23rd ICDE World Conference on Open Learnin and Distance Education: 'Flexible Education for All: Open -Global - Innovative', Maastricht, the Netherlands, 07-10 June 2009. Retrieved January 12, 2014, from http://www.unisa.ac.za/contents/about/principle/docs/ICDEMaastricht250609.pdf

Price, S. (2009). Future directions for career choice research in nursing: A discussion paper. International Journal of Nursing Studies, 46, 268-276. PMID: 18775535, http://dx.doi.org/10.1016/j.ijnurstu.2008.07.011

Raburu, P.A. (2015). Motivation of women academics and balancing family and career. Journal of Educational and Social Research, 5(1), 359-370. http://dx.doi. org/10.5901/jesr.2015.v5n1p359
Ravindaran, B., \& Baral, R. (2013). Factors influencing the attitudes, behaviours and career success of re-entry women: An Indian perspective. Proceedings of 8th Asian Business Research Conference, Bangkok, Thailand, 01-02 April 2013.

Reimers-Hild, C.L., Fritz, S., \& King, J.W. (2007). Entrepreneurial career development: Using human capital, social capital, and distance education to achieve success. Kimmel Education and Research Center - Faculty \& Staff Publications. Paper 1. Retrieved January 12, 2014, from http://digitalcommons.unl.edu/ kimmelfacpub/1

Reuben, S., \& Bobat, S. (2014). Constructing racial hierarchies of skill - Experiencing affirmative action in a South African organisation: A qualitative review. South African Journal of Industrial Psychology, 40(1), 1-12. http://dx.doi.org/10.4102/ sajip.v40i1.1158

Rhodes, H. (2000). Mid-life career change to home-based self-employment in a group of women. Unpublished master's dissertation. British Columbia: Faculty of Education, Simon Fraser University.

Riordan, S., \& Louw-Potgieter, J. (2011). Career success of women academics in South Africa. South African Journal of Psychology, 41(2), 157-172. http://dx.doi. org/10.1177/008124631104100205

Rubin, H.J., \& Rubin, I. (2005). Qualitative interviewing: The art of hearing data. Thousand Oaks, CA: Sage.

Sasithornsaowapa, N. (2013). Female executive career success and satisfaction in Bangkok, Thailand. International Journal of Social, Education, Economics and Management Engineering, 7(8), 1130-1132.

Savickas, M.L. (2011). New questions for vocational psychology: Premises, paradigms, and practices. Journal of Career Assessment, 19(3), 251-258. http://dx.doi. arg/10.1177/1069072710395532

Schreuder, D., \&Coetzee, M. (2012). A review of four decades of organisational career research by academia in South Africa. South African Journal of Human Resource Management, 10(2), 1-10. http://dx.doi.org/10.4102/sajhrm.v10i2.474

Sedibe, M. (2011). Inequality of access to resources in previously disadvantaged South African high schools. Journal of Social Sciences, 28(2), 129-135.

Seibert, S.E., \& Kraimer, M.L. (2001). The five factor model of personality and career success. Journal of Vocational Behavior, 58, 1-21. http://dx.doi.org/10.1006/ jvbe.2000.1757

Stead, G.B., \& Watson, M.B. (2006). Career psychology in the South African context. (2nd edn.). Pretoria: Van Schaik Publishers.

Sullivan, S.E. (1999). The changing nature of careers: A review and research agenda. Journal of Management, 25(3), 457-484. http://dx.doi.org/10.1016/S01492063(99)00009-4

Sullivan, S.E., \& Baruch, Y. (2009). Advances in career theory and research: A critical review and agenda for future exploration. Journal of Management, 35(6), 15421571. http://dx.doi.org/10.1177/0149206309350082

Teo, T., Lord, L., \& Nowak, M. (2014). Career success: Leadership of women in the resources sector of Western Australia. World Review of Business Research, 4(2), 160-175.

Themba, M.A., Oosthuizen, R.M., \& Coetzee, M. (2012). Exploring socio-demographic differences in career maturity in the South African military. South African Journal of Labour Relations, 36(1), 8-30.

Thornhill, H., Clare, L., \& May, R. (2004). Escape, enlightenment and endurance: Narratives of recovery from psychosis. Anthropology and Medicine, 11, 181-199. http://dx.doi.org/10.1080/13648470410001678677

Vishnevsky, T., \& Beanlands, H. (2004). Interpreting research in nephrology nursing. Nephrology Nursing Journal, 31, 234-238.

Walter, M. (2006). Social science methods: An Australian perspective. Oxford, New York, NY: Oxford University Press.

Watt, H.M.G., Richardson, P.W., \& Wilkins, K. (2014). Profiles of professional engagement and career development aspirations among USA preservice teachers. International Journal of Educational Research, 65, 23-40. http://dx.doi. org/10.1016/j.ijer.2013.09.008

Yet-Mee, L., Peng, T.L., \& Yin-Fah, B.C. (2013). A study on women's career advancement in Malaysia. Journal of Human and Social Science Research, 2(1), 21-34. 